\title{
SELECTION OF MICROBES AND CONDITIONS THAT INDUCED BIO-CRACKING OF BRANCHED HYDROCARBON SQUALANE
}

\author{
I. Gailiūtè, S. Grigiškis, G. Žèkaitė, V. Čipinytė \\ JSC "Biocentras", V.Graičiūno st. 10, 02241 Vilnius, Lithuania \\ Ph.: + (370) 526613 13, fax: + (370) 526024 54, e-mail: biocentras@ biocentras.lt
}

\begin{abstract}
Biological oil hydrocarbons degradation is a complicated process, influenced by hydrocarbons properties, microorganisms and environmental conditions. The aim of this work was to select microbial strain, capable of degrading heavy branched hydrocarbons for further application in environment remediation and bio-cracking. Also, it was necessary to select optimal conditions (temperature, pH, concentration and etc.) for selected microbial strain degrading heavy branched hydrocarbons. Since crude oil and its products are mixtures of various hydrocarbons, at the first step of selection the ability of the strains to degrade individual hydrocarbons was investigated. Squalane was used as a test substrate. 10 microbial cultures belonging to genus Arthrobacter and obtained from culture collection of JSC "Biocentras" were used for the investigations. Gas chromatography analysis revealed that Arthrobacter sp NJ5 strain had the highest effectiveness (67\%) in degradation of heavy branched oil hydrocarbon (Squalane) to shorter chain intermediates. So, Arthrobacter sp NJ5 could be applied in bio-cracking. For the application in industry, more detailed analyses are needed.
\end{abstract}

Keywords: Arthrobacter, bio-cracking, heavy branched hydrocarbon squalane.

\section{Introduction}

As oil industry continuously grows and consumption rates of fuels are getting higher, oil derived pollutants are blocking up the environment [1,2]. Hydrocarbons, that are the main oil components (up to $98 \%$ ), consist of carbon and hydrogen. Oil hydrocarbons differ in their structure and molecular mass $[3,4]$. According to their structure hydrocarbons are divided into several classes: alkanes, cycloalkanes, aromatic hydrocarbons and alkenes [3, 5, 6, 7]. A different class of polar hydrocarbons are the asphaltenes.

If an oil spill occurs, the volatile light fractions evaporate, while the higher molecular mass hydrocarbons can remain in the environment for a long period of time. Since heavy hydrocarbons have complex structures their degradation can be prolonged and ineffective. The most problematic are polyaromatic and branched oil hydrocarbons (that have more than 28 carbon atoms), tar and asphaltenes $[8,6]$. These hydrocarbons under normal conditions are thick or hard, therefore, they are almost unavailable for oil-oxidizing microorganisms to degrade. Indeed, oil-oxidizing microbes, that can degrade heavy hydrocarbons, have been poorly investigated.

Biological oil hydrocarbon degradation is a complicated complex process influenced by the nature of hydrocarbons, environmental conditions and by microorganisms themselves [6]. Claude E. ZoBell was one of the first researches, who in 1946 reported, that most of the microorganisms found in nature could use hydrocarbons as the sole source of carbon and energy for their reproduction and growth [9]. The most of microorganisms that degrade hydrocarbons are bacteria [7]. For example, bacteria belonging to Pseudomonas, Achromobacter, Arthrobacter, Micrococus, Nacardia, Vibrio, Acinetobacter, Bacillus, Corynebacterium, Flovabacterium genus are known to degrade hydrocarbons [10, 11, 12].

Other reseachers have reported, that the amount of oil-oxidizing microbes becomes greater when their environment is polluted with hydrocarbons $[13,14,15,16]$.

Oil-oxidizing microorganism growth and biological degradation length depends on many environmental factors. The main factors determining the effectiveness of degradation are: the hydrocarbon mixture composition, physical properties, temperature, nutrients availability, $\mathrm{pH}$, microorganisms $[17,6]$. 
Heavy oil fraction degradation process, when short chain hydrocarbons are created, is called cracking. Over the last years an alternative to chemical and thermal cracking was introduced, that uses biological processes, called bio-cracking. A few laboratories have started experiments in 2009 with Achromobacter, Leptospirillum, Pseudomonas, Sulfolobus and Thiobacillus sp bacteria in order to use them in bio-cracking [18]. If researches were successful and bio-cracking technology was created, it would be ecological and effective in extracting lighter fractions of hydrocarbons from the useless heavy crude oil.

The aim of this work was to select microbes and evaluate conditions that induce bio-cracking of the branched hydrocarbon - squalane.

\section{Materials and methods}

Heavy branched hydrocarbons. Heavy branched hydrocarbon squalane $\left(\mathrm{C}_{30} \mathrm{H}_{62}\right)$ was selected as substrate. According to IUPAC nomenclature this compound is known as 2,6,10,15,19,23-hexamethyltetracosane.

Microorganisms. The following strains of hydrocarbon degrading bacteria belonging to Arthrobacter genus were used: sp N3, NJ1, NJ5, NJ9, NJ6, Pr82, Mž811, K11, M1 and M2.

Media. Nutrient agar (Oxoid, Basingstoke, UK) was used for plating microbial strains, and nutrient broth (Oxoid, Basingstoke, UK) was used for the subculture and preculture of the strains. To investigate the ability of the strains to degrade squalane, a mineral medium was used. The mineral medium had the following composition (g/l): $0.1\left(\mathrm{NH}_{4}\right)_{2} \mathrm{HPO}_{4} ; 0.2 \mathrm{NH}_{4} \mathrm{Cl}$; $0.25 \mathrm{~K}_{2} \mathrm{HPO}_{4} ; 0.25 \mathrm{KH}_{2} \mathrm{PO}_{4} ; 0.02 \mathrm{MnSO}_{4} ; 0.01\left(\mathrm{NH}_{4}\right)_{2} \mathrm{Fe}\left(\mathrm{SO}_{4}\right)_{2} \cdot 6 \mathrm{H}_{2} \mathrm{O} ; 0.01 \mathrm{CaCl}_{2}$ and 0.05 $\left(\mathrm{CH}_{3} \mathrm{COO}\right)_{2} \mathrm{Zn}$.

Biodegradation of squalane. The ability of strains to degrade squalane was investigated in a mineral medium. Cultivation was carried out under sterile conditions in $250 \mathrm{ml}$ flasks with 50 $\mathrm{ml}$ of mineral medium. Heavy branched hydrocarbon squalane $\left(\mathrm{C}_{30} \mathrm{H}_{62}\right)$ was used as substrate, wich concentration was $0.2 \mathrm{~g} / \mathrm{l}$. After inoculation with $10 \%$ of volume blank flasks were incubated on a rotary shaker at $30{ }^{\circ} \mathrm{C}$ and $200 \mathrm{rpm}$. The same cultivation conditions were applied for the testing of correlation between squalane degradation intensity, temperature, medium $\mathrm{pH}$ and squalane concentration.

Squalane degradation dependency on medium $\mathrm{pH}$ was investigated at $\mathrm{pH}$ values of: $4 ; 5 ; 6 ; 7$; $8 ; 9$.

Squalane degradation dependency on temperature was estimated at $5 ; 20 ; 30 ; 40 ; 45^{\circ} \mathrm{C}$; and dependency on concentration was investigated with $0.025 ; 0.2 ; 1 ; 2 ; 3.5 ; 5 \mathrm{mg} / \mathrm{ml}$ of squalane. After $48 \mathrm{~h}$ incubation, the cultures were extracted with equal volume of tetrachlormethane for IR spectroscopy or hexane for GC.

Infrared spectroscopy of squalane. Samples were quantified by petroleum analyzer AN-1 at $1 / \lambda=2930 \mathrm{~cm}^{-1}$ wave length. IR absorption is directly proportional to the concentration of hydrocarbons.

GC analysis of squalane. Samples were quantified by GC system (GC-2010 Plus, Shimadzu, Japan) equipped with a flame-ionization detector and MXT-1 capillary column (Siltek treated stainless steel). Operation conditions were as follows: nitrogen was used as the carrier gas; the injector temperature and detector temperature were 330 and $350{ }^{\circ} \mathrm{C}$, respectively; the column oven temperature was kept at $40^{\circ} \mathrm{C}$ for $1 \mathrm{~min}$ and then raised to $320^{\circ} \mathrm{C}$ at a rate of $10^{\circ} \mathrm{C} \min ^{-1}$.

Biomass measurement. Bacterial growth was measured as optical density (OD) at $600 \mathrm{~nm}$ (with spertrophotometer (UV 1601 Shimadzu).

\section{Results and discussion}

The heavy branched hydrocarbon used for experiments - squalane, is a poorly degradable substrate. It is known since our previous research that Arthrobacter species degrades oil hydrocarbons, therefore we have choosen the following strains of Arthrobacter sp N3, NJ1, 
NJ5, NJ9, NJ6, PR82, MŽ811, KL1, M1 and M2 for testing degradation of heavy branched hydrocarbon squalane.

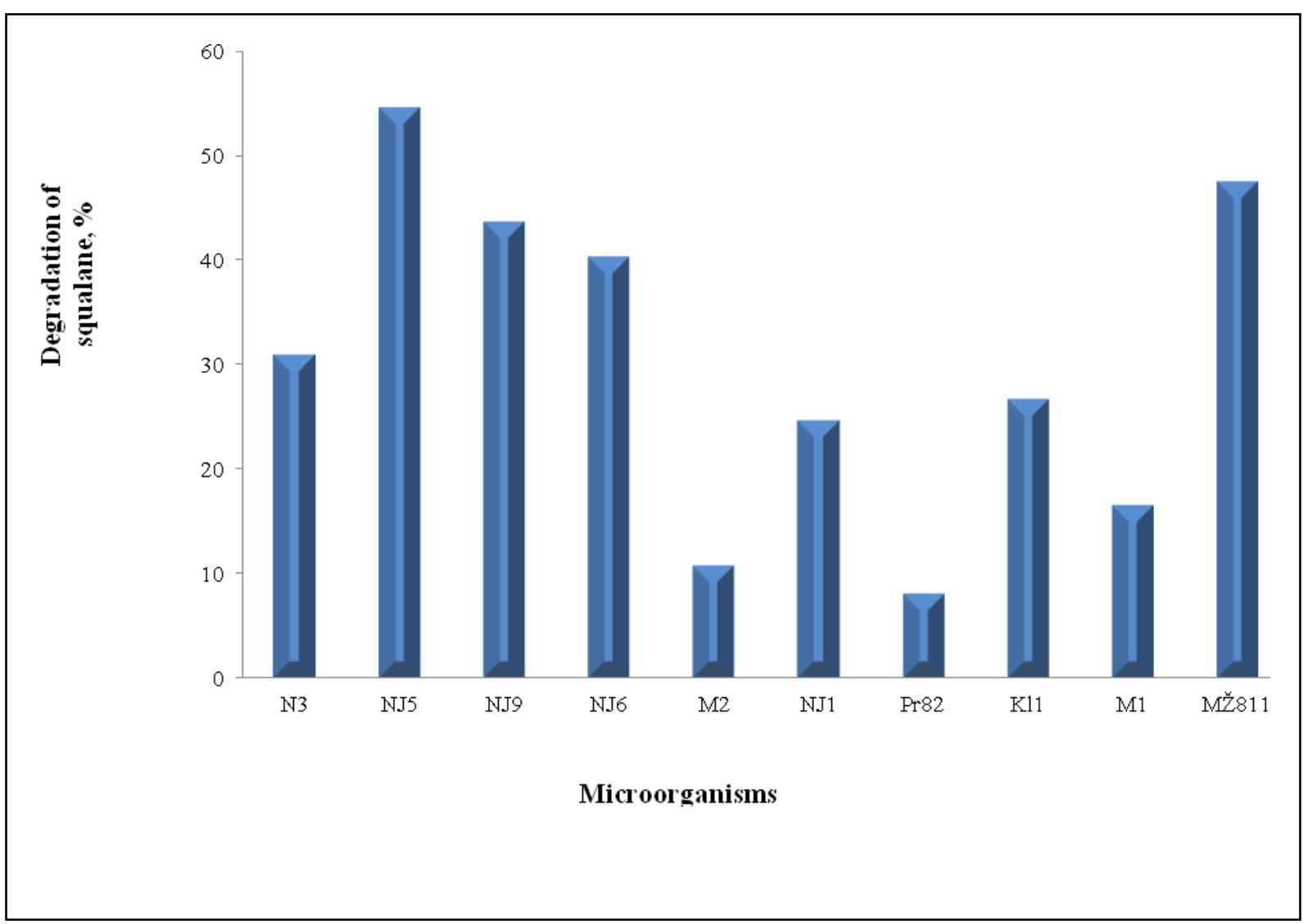

Fig. 1 The effect of hydrocarbon degrading bacteria on squalane biodegradation

Fig.1 results show that the greatest degradation of squalane occurred using strain Arthrobacter sp NJ5, which was chosen for the later experiments.

It is known, that bacterial biomass growth and substrate degradation effectiveness depends on the inoculum's age. Usually microorganisms are taken for biological degradation, when they are in their exponential growth phase, and when their reproductional processes are at peak [2]. Therefore, after selection of the best squalane degrading bacterial strain, correlation between inoculums' age and squalane degradation was investigated (Fig. 2).

Experiments were carried out in order to determine the influence of different cell phase (exponential and stationary) on squalane degradation levels.

Substrate degradation level depends on the inoculums growth time. The greatest squalane degradation $(54.5 \%)$ occured when substrate was inoculated with 18-hour old inoculum, which was in its stationary phase.

After that, the effect of initial medium $\mathrm{pH}$, temperature and substrate concentration of squalane degradation with Arthrobacter sp. NJ5 strain was investigated. 


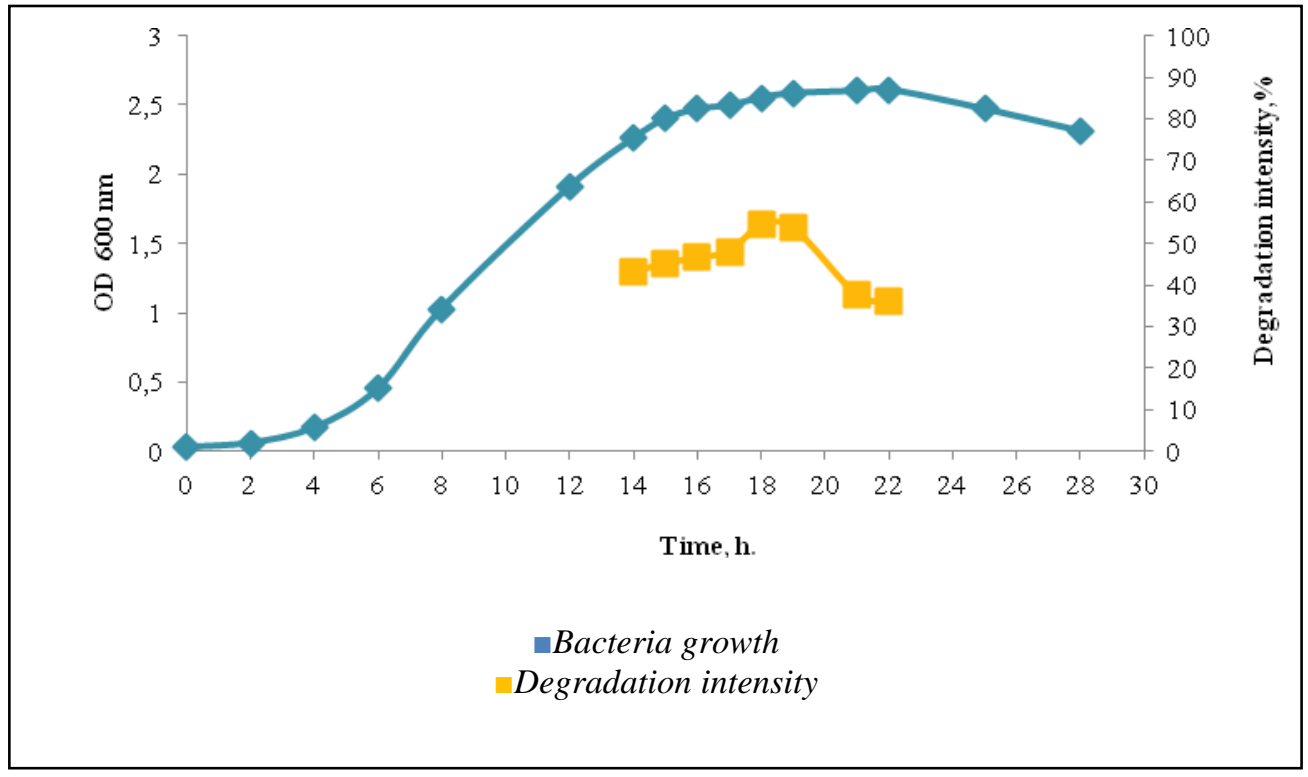

Fig. 2 NJ5 inoculums age influence on squalane degradation intensity

During the selection of an optimal mediun $\mathrm{pH}$, the maximum substrate degradation was achieved at $\mathrm{pH}$ range 6-7, while the more alkaline or acidic medium has prevented effective squalane degradation (Fig. 3).

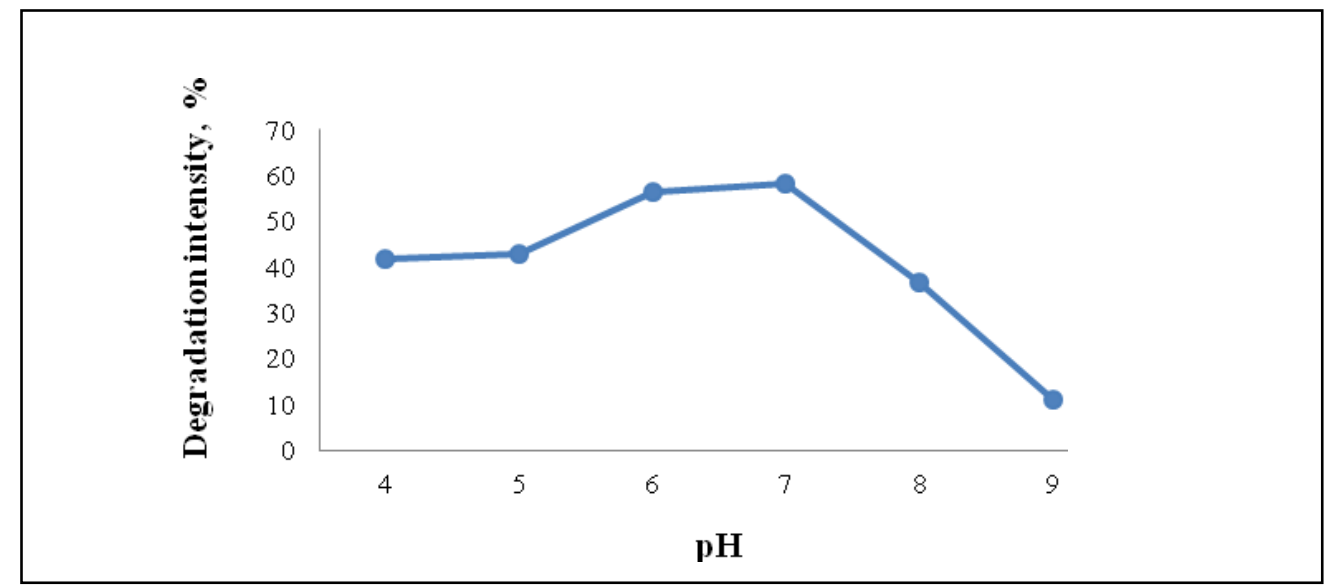

Fig. 3 Dependency of squalane degradation by Arthrobacter sp NJ5 strain on medium pH

Microbiological hydrocarbon degradation process effectiveness is influenced by the substrate concentration as well, which can be inhibitory or even toxic to oil-oxidizing microorganisms $[1,5]$. Therefore, the sp NJ5 strain oxidizing properties were tested against the hydrocarbon substrate. Results revealed that, when substrate concentration in medium was increased from 0.025 to $2.0 \mathrm{mg} / \mathrm{ml}$, substrate degradation level has risen, but higher concentrations (up to 5.0 $\mathrm{mg} / \mathrm{ml}$ ) slowed down the intensity of degradation. The best substrate degradation was observed when the initial squalane concentration was at $2.0 \mathrm{mg} / \mathrm{ml}$ (Fig. 4). 


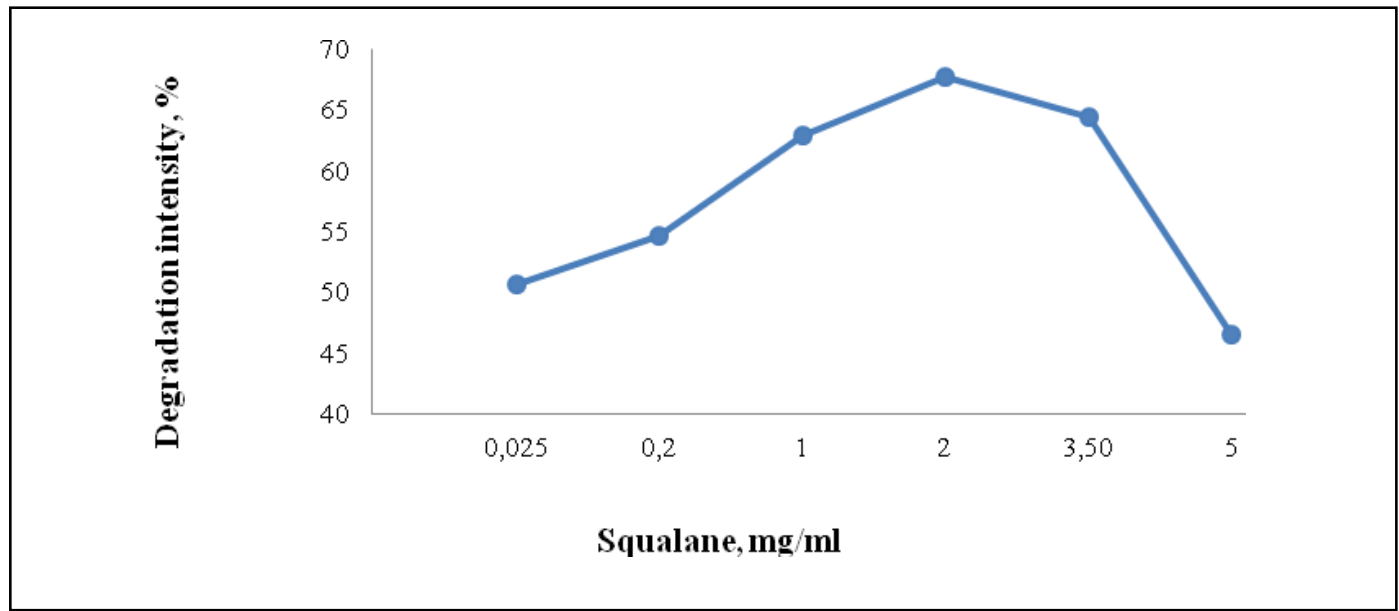

Fig. 4 Dependency of squalane degradation on squalane concentration

After determining the dependency of degradation on squalane concentration, temperature regime was selected for the most efficient pollutant degradation. It was found that the rise in temperature from 5 to $35^{\circ} \mathrm{C}$ promotes degradation of substrate and it is highest at $35^{\circ} \mathrm{C}$; however, degradation level drops at $35-45^{\circ} \mathrm{C}$ temperatures' interval (Fig. 5).

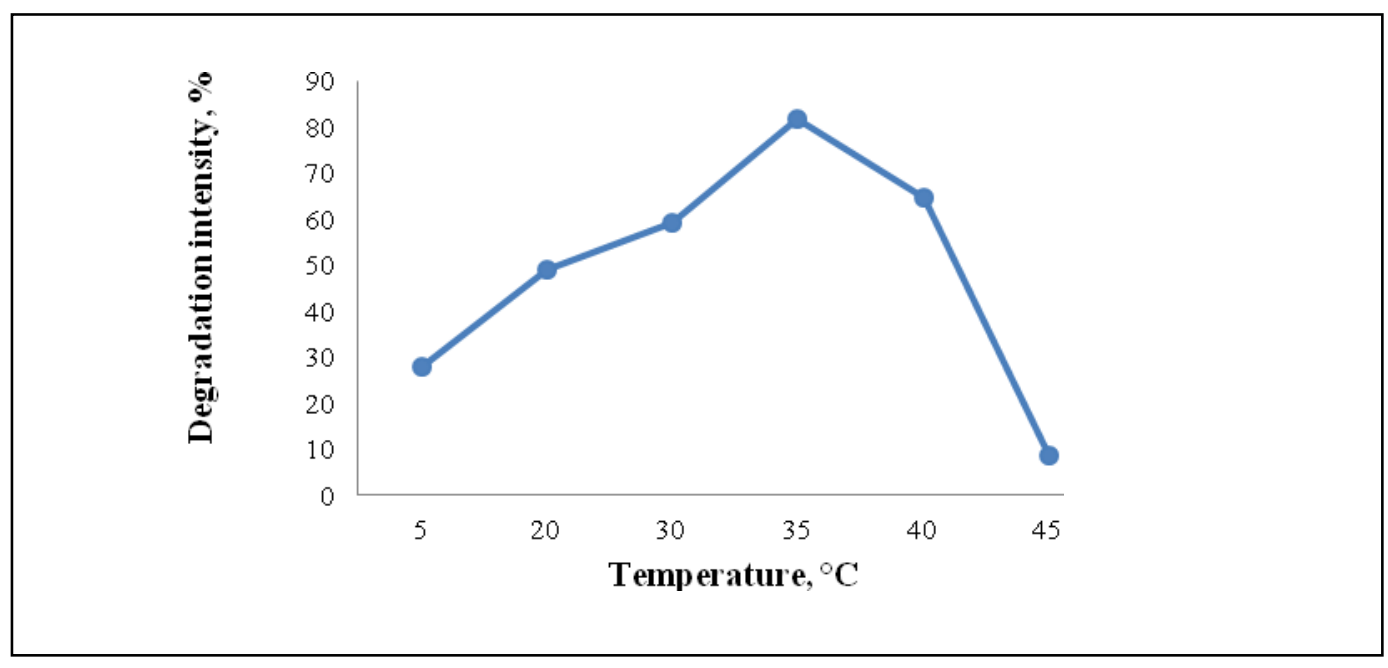

Fig. 5 Dependency of squalane degradation on temperature

Gas chromatographic analysis was carried out to investigate quantitative and qualitative changes of squalane during biodegradation by selected strain sp NJ5. In biodegradation experiment initial concentration of squalane and inoculate in mineral medium was $1 \mathrm{mg} / \mathrm{ml}$ and $10 \%$, respectively. Inoculated flasks were incubated at $35^{\circ} \mathrm{C}$ and $200 \mathrm{rpm}$ for $48 \mathrm{~h}$. Control test was performed at the same conditions, except the inoculate. Results of qualitative analysis are shown in (Fig. 6).

As it is seen from chromatograms, during incubation squalane was degraded into compounds with smaller molecular weight (1-7 peaks in Fig.6.b) in comparison to the control (Fig. 6a). After exposure to NJ5 strain only $0.33 \mathrm{mg} / \mathrm{ml}$ of squalane was found, i.e. $67 \%$ of substrate was degraded (Table 1). Using IR spectroscopy for squalane determination, $62.8 \%$ of substrate was found degraded. Both methods showed very similar results. 


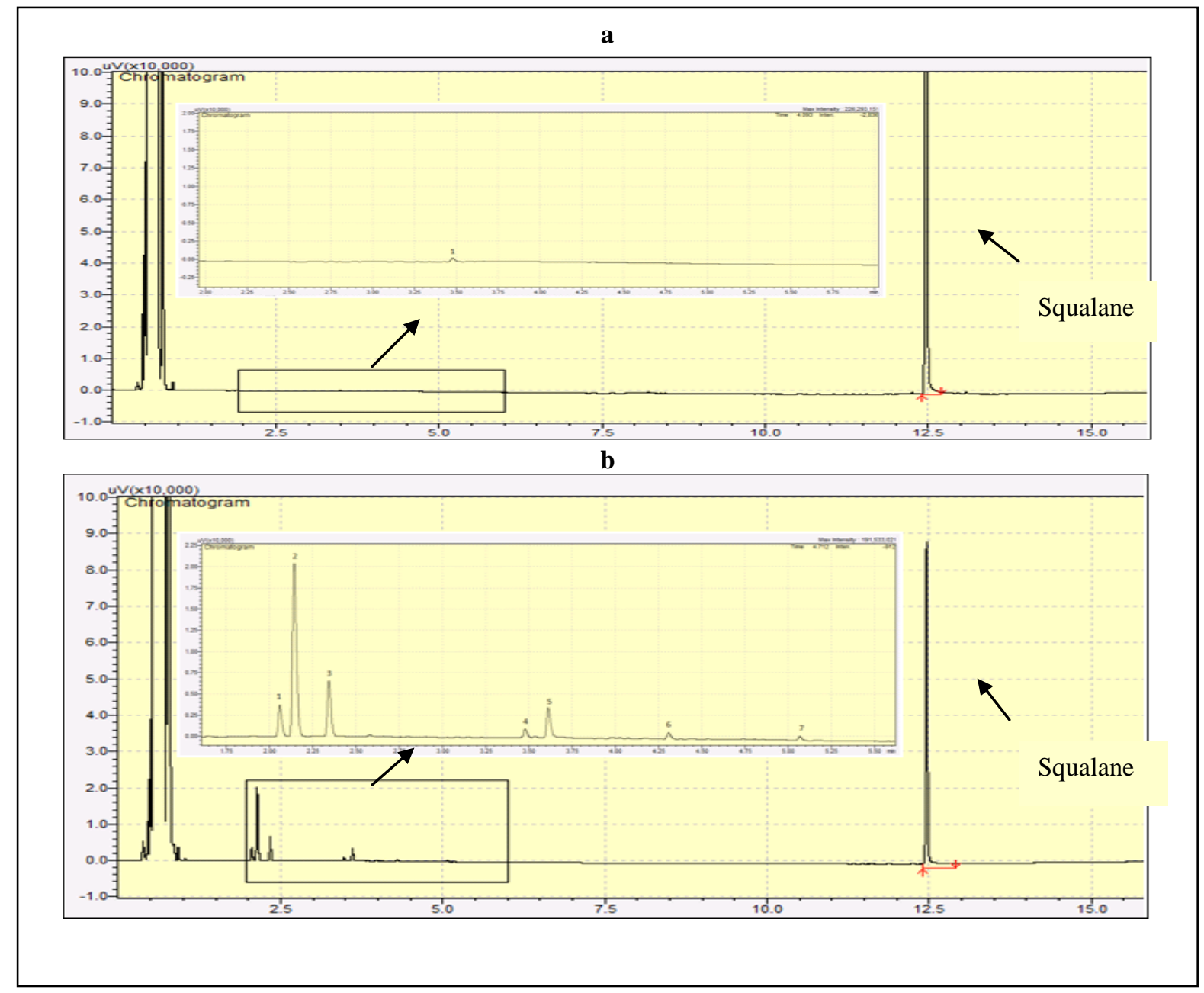

Fig. 6 Gas chromatograms of squalane (a - control test; $\mathbf{b}$ - after biodegradation by sp. NJ5 strain)

Table 1.

Results of squalane GC chromatograms before and after degradation

\begin{tabular}{|c|c|c|c|c|}
\hline Peak & $\begin{array}{c}\text { Peak retention } \\
\text { time, } \boldsymbol{s}\end{array}$ & Peak area & Peak height & Concentration \\
\hline \multicolumn{5}{|c|}{ Control } \\
\hline Squalane & 12.470 & 670256.3 & 344508.2 & 1.03163 \\
\hline \multicolumn{5}{|c|}{ Sampler after degradation } \\
\hline 1 & 2.058 & 5294.7 & 3626.3 & - \\
\hline 2 & 2.141 & 33223.8 & 20118.5 & - \\
\hline 3 & 2.342 & 9495.4 & 6488.8 & - \\
\hline 4 & 3.478 & 1473.9 & 1031.9 & - \\
\hline 5 & 3.611 & 5552.1 & 3540.7 & - \\
\hline 6 & 4.308 & 1151.5 & 775.9 & 0.33095 \\
\hline 7 & 5.067 & 666.2 & 463.3 & 89248.8 \\
\hline 8 squalane & 12.464 & 210463.1 & & - \\
\hline
\end{tabular}




\section{Conclusions}

10 strains of Arthrobacter were investigated, and one of them - sp NJ5 showed the best results in heavy branched hydrocarbon squalane degradation activity. The highest substrate degradation level $(54.5 \%)$ was reached using 18 hour old inoculate culture, which was in stationary growth phase. The best squalane degradation $(58.3 \%)$ was ocurred using Atrhrobacter $s p$ NJ5 strain when the initial medium pH was 7.0. What is more, when the initial squalane concentration was $2.0 \mathrm{mg} / \mathrm{ml}$, the highest substrate degradation level $(67.7 \%)$ was reached. Also it was determined, that the optimal squalane degradation temperature is $35^{\circ} \mathrm{C}$.

Therefore, the selected Arthrobacter sp NJ5 strain can be used for biological environment remediation from heavy oil hydrocarbon fractions. As the selected Arthrobacter sp NJ5 strain is effective in degrading the heavy branched hydrocarbons into smaller compounds $(67 \%)$, and can be used in bio-cracking. However, for the further employment in industry more detailed research is needed.

\section{References}

1. Hasanuzzamana, M.; Ueno, A.; Ito, H.; Ito, Y.; Yamamoto, Y.; Yumotoc, I.; Okuyama, H. Degradation of long-chain n-alkanes (C36 and $\mathrm{C} 40)$ by Pseudomonas aeruginosa strain WatG. International Biodeterioration \& Biodegradation, 2007, nr. 59, p. 40-43.

2. Margesin, R.; Schinner, F. Biodegradation and bioremediation of hydrocarbons in extreme environments. Appl Microbiol Biotechnol, 2001, nr. 56, p. 650-663

3. Jankevičius, K.; Liužinas, R. Aplinkos biologinis valymas. Vilnius: Apyaušris, 2003. ISBN 9955-609-00-1

4. Wauquier, J.P. Petroleum refining. Paris: Editions Technip, 1994. ISBN-2-7108-0686-X.

5. Okoh, A.I. Biodegradation alternative in the cleanup of petroleum hydrocarbon pollutants. Biotechnology and Molecular Biology Review, 2006, nr. 2, p. 38-50. ISSN 1538-2273.

6. Singh, A.; Ward, O. P. Biodegradation and bioremediation. Canada: Springer, 2004. ISBN-3-540-21101-2.

7. Environmental Biotechnology. Hydrocarbon Degradation. http://www.molecular-plantbiotechnology.info/environmental-biotechnology/hydrocarbon-degradation.htm

8. Kato, T.; Haruki, M.; Imanaka, T.; Morikawa, M.; Kanaya, S. Isolation and characterization of long-chainalkane degrading Bacillus thermoleovorans from deep subterranean petroleum reservoirs. Journal of Bioscience and Bioengineering, 2001, nr. 91, p. 64-70.

9. ZoBell, C. E. Action of microorganisms on hydrocarbons. Bacteriol. Rev.1946. 10:1-49.

10. Atlas, R.M. Microbial degradation of petroleum hydrocarbons: an environmental perspective. Microbiological Reviews, 1981, nr. 45, p. 180-209.

11. Ollivier, B.; Magot, M. 2005. Petroleum microbiology. American Society for Microbiology: ASM press.p. ISBN 1-55581-327-5.

12. Stroud, J.L.; Paton, G.I.; Semple, K.T. Microbe - aliphatic hydrocarbon interactions in soil: implications for biodegradation and bioremediation. Journal of Applied Microbiology, 2007, nr. 102, p. 1239-1253

13. Brock, T.D.; Madigan, M.T.; Biology of Microorganisms (Sixth Edition). New Jersey: Prentice Hall, 1991. ISBN-0-13-083817-9

14. Roberts, E.R. 1995. Bioremediation of petroleum contaminated sites. CRC press.p. ISBN 0-87371-832-1.

15. Saadoun, I.; Munir, J.M.; Hameed, K.M.; Shawaqfah, M. Microbial populations of crude oil spill polluted soils at the Jordan - Iraq desert (The Badia region). Brazilian Journal of Microbiology, 2008, nr. 39, p. 453456. ISSN $1517-8382$.

16. Van Hamme, J.D.; Singh, A.; Ward, O.P. Recent advances in petroleum microbiology. Microbiology and molecular biology reviews, 2003, nr. 67, p. 503-549.

17. Montiel, C.; Quintero, R.; Aburto, J. Petroleum biotechnology: Technology trends for the muture. African Journal of Biotechnology, 2009, nr. 12, p. 2661. ISSN-1684-5315.

18. Chatterjee, S.; Chattopadhyay, P.; Subhasita, R.; Sukanta, K.S. Bioremediation: a tool for cleaning polluted environments. Journal of Applied Biosciences, 2008, nr. 11, p. 594-601. 